\title{
Esthetic considerations for anterior implant-supported prostheses: focus on surgical and prosthetic treatment
}

\author{
Yeon-Hee Park', Seung-Geun Ahn', Kyoung-A Kim², Jae-Min Seo* \\ 'Department of Prosthodontics, School of Dentistry, Jeonbuk National University, Research Institute of Clinical Medicine of \\ Jeonbuk National University- Biomedical Research Institute of Jeonbuk National University Hospital, Jeonju, Republic of Korea \\ ${ }^{2}$ Department of Dentistry, Daejeon Konyang Medical Center, Konyang University, School of Medicine, Daejeon, Republic of Korea
}

\begin{abstract}
As the increased certainty of osseointegration, new parameters are now being used to assess implant success. Accordingly, patients' and clinicians' high demands and expectation for esthetics have expanded and implant-supported restorations show better esthetic outcomes. The pre-implant treatment planning process, the implant surgical steps and the post-surgery prosthetic process can affect all esthetic outcomes. Prevention of esthetic implant failures can be achieved by appropriate treatment at each stage, considering the 3 factors of alveolar bone, soft tissue, and implants. It is necessary to achieve the esthetic implant prostheses followings: minimal invasive surgery, bone augmentation, ideal 3-dimensional implant position, peri-implant soft tissue management, and provisional restorations to optimize peri-implant soft tissue architecture. (J Dent Rehabil Appl Sci 2021;37(4):186-98)
\end{abstract}

Key words: dental implant; dental esthetics; dental prosthesis, implant-supported; marginal gingiva; interdental papilla

\section{서론}

성공적인 임플란트 수복의 평가요소는 다양한 변수가 있다. 임플란트 치료의 초창기의 성공요인은 골유착의 여부에 있었다면, 최근에는 골유착의 성공률이 높아짐에 따라 임플란트의 성공여부를 판단하는데 새로운 변수가 대두되고 있다. 이러한 변수에는 임플란트 주변 연조직 높이, 보철물 길이, 환자의 주관적 평가 등이 포함되며, 이는 임플란트 주변의 연조직이 최대한 자연치아와 유사 한 형태가 되도록 기대하기 때문이다. ${ }^{1,2}$ 환자도 기능적인 만족도와 더불어 심미에 대한 높은 기대감 및 요구를 하 고 있다. ${ }^{3}$ 이러한 이유로 전치부 부분 무치악에 대한 임플 란트 치료는 기능적 성공 이외에 심미적 성공에 대한 기 준도 높아졌다고 할 수 있다. ${ }^{4}$ 전치부 임플란트 치료의

\footnotetext{
*Correspondence to: Jae-Min Seo

Professor, Department of Prosthodontics, School of Dentistry and Institute of Oral Bio-Science, Jeonbuk National University, 567, Baekje-daero, Deokjin-gu, Jeonju, 54896, Republic of Korea

Tel: +82-63-250-2696, Fax: +82-63-250-2218, E-mail: jmseo@jbnu.ac.kr Received: August 19, 2021/Last Revision: November 18, 2021/Accepted: November 23, 2021
}

성공적인 결과를 이루는데 있어서는 환자의 협조도, 술 자의 경험, 지식 및 숙련도 이외에 술 전 치료 계획 수립, 수술 및 보철수복 과정, 보철수복 후의 정기적인 검진 과 정 등 영향을 미치는 요인이 많다. ${ }^{5}$ 특히 심미적인 요구와 기대가 높은 환자의 경우, 최종 보철물이 자연치와 유사 할 것을 기대하기 때문에 이런 환자군에서 전치부 부분 무치악을 임플란트를 통해 심미적으로 재건하는 것은 더 욱 어렵다. ${ }^{5}$ 그러나 최근 연구에 따르면 임플란트 고정성 보철수복이 발치 전의 자연치아와 비교하여 더 우수한 심미적 결과를 보였으며, 이에 대한 환자의 심미적 만족 도도 매우 높아졌다고 보고되었다. ${ }^{6}$

상악 전치부 자연치는 치경부 부위가 $4.5-7 \mathrm{~mm}$ 의 직 경을 지니고 순구개면 폭경이 더 넓은 타원형인데 반해 임플란트의 직경은 $5 \mathrm{~mm}$ 이하로 자연치와 비교하였을

Copyright@ 2021 The Korean Academy of Stomatognathic Function and Occlusion. (c) It is identical to Creative Commons Non-Commercial License. 
Table 1. On the basis of objective indices, esthetic failures in implant dentistry can be categorized as pink-tissue failures and white-tissue failures (Fuentealba and Jofre, 2015) ${ }^{1}$

\begin{tabular}{ll}
\hline \multicolumn{1}{c}{ Pink-tissue failures } & \multicolumn{1}{c}{ White-tissue failures } \\
\hline (1) Facial recession & (1) The general form of the tooth \\
(2) Gingival asymmetry & (2) The outline and volume of the clinical crown \\
(3) Papillary deficiency & (3) Color (hue and value) \\
(4) Graying of the gingival tissue & (4) Surface texture \\
\end{tabular}

때 임플란트의 지름이 작고 원형이기 때문에 치경부 부위 에서 심미적인 요소를 충족시키기 매우 어렵다. 특히 치 아가 상실된 이후 골 손실이 우선적으로 순구개 폭경에 서 일어나기 때문에 적절한 직경의 임플란트 식립을 위해 서는 더 많은 골조직의 증강이 요구된다. 더불어, 임플란 트 주위 조직은 조직학 및 형태학적으로 자연치아의 주 위조직과 매우 달라 임플란트를 이용한 심미 치료는 그 결과를 예측하기 어렵다는 단점도 있다. 그 결과, 전치부 임플란트의 심미성을 얻기 위해서는 특수한 수술적, 보철 적 접근이 필요하다고 할 수 있다. ${ }^{7}$

객관적인 지표를 기반으로 한 임플란트의 심미적 실 패(esthetic failure)는 pink-tissue failures와 white-tissue failures로 분류할 수 있다(Table 1). ${ }^{1}$

이런 임플란트의 심미적 실패는 치조골, 연조직, 임플 란트와 같은 3 가지 요소에 대해 임플란트 식립 전의 과 정, 식립 시 과정, 식립 후 보철수복 과정에서 적절한 처 치를 통하여 예방할 수 있다. 따라서 본 연구에서는 임플 란트 주위 연조직을 변연치은(marginal gingiva)과 치간 유두(interdental papilla)로 나누어 각각의 심미적 결과를 달성하기 위해 필요한 외과적, 보철적 고려사항을 설명하 고자 한다.

\section{문헌고찰}

\section{변연치은 (Marginal gingiva)}

전치부 임플란트는 환자의 직접적인 시야에 의해 인접 한 자연치아와 즉각적인 비교가 되기 때문에 요구되는 심미적 기준이 구치부 임플란트보다 높다. 따라서 인접 자연치아와 비교하여 임플란트 주위에 적절한 높이와 두 께를 가지는 변연치은을 획득하는 것은 매우 중요하다.

기본적으로 연조직은 하부에 존재하는 골의 외적 표 현으로 변연치은 높이는 임플란트를 식립한 부위의 골
높이와 밀접한 관계를 가진다. ${ }^{5}$ 환자마다 다르지만 일반 적으로 협측 치조골 상방으로 약 $3-4 \mathrm{~mm}$ 정도에 연조 직 높이가 형성되기 때문에 이미 흡수가 진행된 치조골 높이에 맞춰 식립된 임플란트의 보철물은 치관이 길어지 게 된다(Fig. 1). ${ }^{8}$ 따라서 치조골이 수직적으로 흡수된 경 우, 정상적인 주변치아의 협측 치조골 높이 수준까지 치 조골을 회복시키는 과정이 임플란트 식립 전에 선행되거 나, 임플란트 식립과 동반되어야만 변연치은의 적절한 높이를 얻을 수 있다. 상실부위를 중심으로 양측 치간골 (interproximal bone)의 가장 높은 곳을 연결하는 가상의 선까지는 골이식을 통해 술자가 치조골 높이를 회복시켜 줄 수 있으며, 이렇게 회복된 치조골에 임플란트 플랫폼 이 인접치아의 협측 치조골과 비슷한 높이 수준으로 식 립되어야 심미적인 치은연 높이를 기대할 수 있다.

정상적이거나, 정상적으로 회복된 치조골 높이에서 임 플란트의 식립 깊이는 정상깊이 식립(crestal placement) 혹은 정상깊이보다 침하식립(subcrestal placement)으 로 결정할 수 있다. 침하식립의 장점은 술 후에 일어나 는 치조골의 생리적 흡수를 보상할 수 있고, 상부 보철물 의 자연스러운 출현윤곽을 형성하기 위한 수직적 높이를
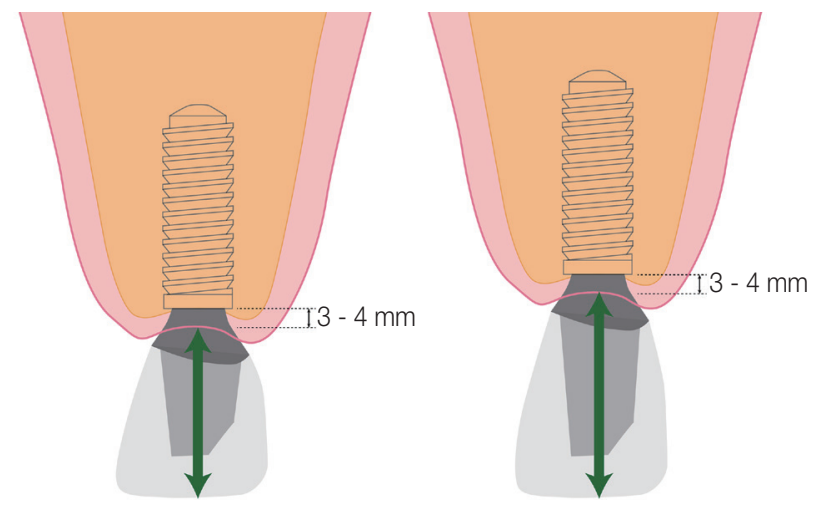

Fig. 1. Unesthetic long crown resulting from excessive depth of implant placement in atrophic alveolus. 
충분히 얻을 수 있다는 점이다. ${ }^{9}$ 임플란트 몸체와 지대 주 사이의 취약한 계면을 가진 고전적인 임플란트 ${ }^{10,11}$ 가 morse taper connection ${ }^{12-15}$ 과 플랫폼 스위칭(platform switching) 개념 ${ }^{16,17}$ 을 적용시킨 임플란트로 발전하면서 임플란트 주위 골이 더 잘 보존되는 결과를 가져오게 되 었다. 그러나 이러한 최신의 임플란트에서도 식립 깊이에 대해서는 여전히 논란이 되고 있다. ${ }^{9,18}$

플랫폼 스위칭 개념은 임플란트 몸체와 지대주의 계면 하방으로의 골흡수를 막아주는 역할을 하지만, 계면 상 방으로의 치조골을 유지시키는 특별한 기전을 가지고 있 는 것은 아니기에 정상깊이보다 너무 깊게 침하식립을 할 경우 환자에 따라 계면 상방의 골이 계면까지 흡수되 면서 연조직이 함께 퇴축될 가능성이 있다(Fig. 2). 따라 서 인접치아의 협측골 높이 수준과 비교하여 너무 깊게 임플란트를 식립하는 경우 플랫폼(계면) 상방의 골흡수 를 막을 수 없기 때문에, 경우에 따라 인접치아와 비교하

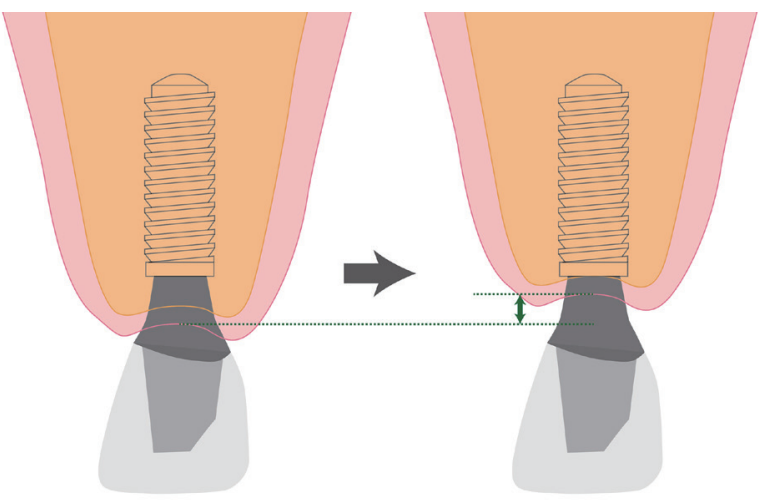

Fig. 2. Even the implant with platform switching, more apically placed implants cannot prevent bone resorption above the platform. This could lead to a marginal gingiva recession.
여 깊게 식립한 만큼 변연치은의 퇴축이 발생할 수 있다.

반대로 인접치아보다 임플란트가 얕게 식립되는 경우 도 있다. 보통 이런 경우는 전치부 자연치가 발거된 후, 취약한 협측골이 수평적으로 흡수되면서 일반적으로 협 측골보다 높은 위치에 있는 설측골과 합쳐지면서 치유되 는 현상 때문에 발생한다. 발치와가 치유되면, 발치 전보 다는 수평적으로는 위축되었지만, 협측골에 비해 상대적 으로 높은 위치에 남아있는 설측 치조골쪽에 작은 직경 의 임플란트를 골정 높이에 맞춰 식립하기 되면, 결과적 으로 협측 기준으로 주변 자연치아보다 임플란트가 치관 쪽으로 위치하게 되어 얕게 식립하게 되는 결과를 초래 하게 된다(Fig. 3). ${ }^{19,20}$ 이렇게 임플란트가 얕게 식립하게 되면 연조직이 주변치아보다 치관쪽으로 위치하게 되어 치관이 짧아지는 심미적인 문제를 유발하고, 위생관리가 어려운 협측 플랜지(flange)가 생기거나 급격한 출현윤곽 을 가지는 보철물이 만들어지기 쉽다. ${ }^{8}$ 또 치은연하부의 형태가 너무 볼록(convex)해지거나, 급격한 출현 윤곽을 가지면 구강위생관리의 어려움이 발생할 수 있고, 임플 란트 플랫폼 상방의 연조직을 과도하게 압박하거나 연조 직 공간을 침범하게 되어 임플란트 주위골 흡수를 유발 할 수도 있다. ${ }^{5,21,22}$

따라서 그림과 같은 해부학적 지표를 참고하면 식립깊 이를 정하는 데 도움이 될 수 있다(Fig. 4). ${ }^{23,24}$ 그러나 이 는 단순히 평균적인 수치로서 환자마다 그 편차가 상당 히 크기 때문에 환자의 해부학적 형태와 인접 자연치아 의 협측 골정의 높이 수준을 방사선학적 영상진단과 수 술과정에서 확인하여 임플란트 식립깊이를 결정하는 것 이 매우 중요하다. ${ }^{25-27}$ 결론적으로 임플란트는 인접치아 의 협측 치조골정과 유사하거나 약간 깊게 식립하되 $(\leq 1$ $\mathrm{mm})$, 임플란트 상방 연조직의 수직적 두께가 얇은 경우

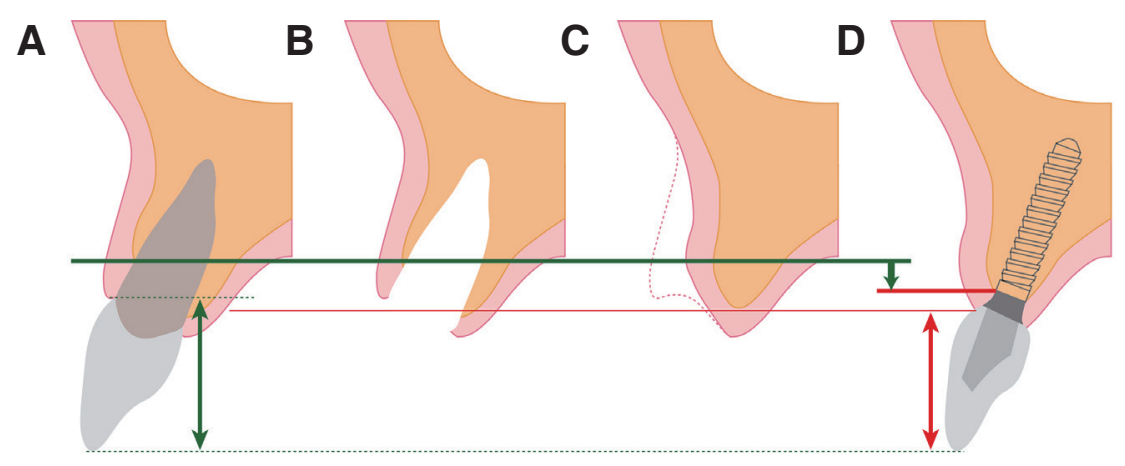

Fig. 3. Shallow implant placement. (A) Natural teeth. (B) Extraction. (C) Bone healing. (D) Palatal placement of narrow implant. 


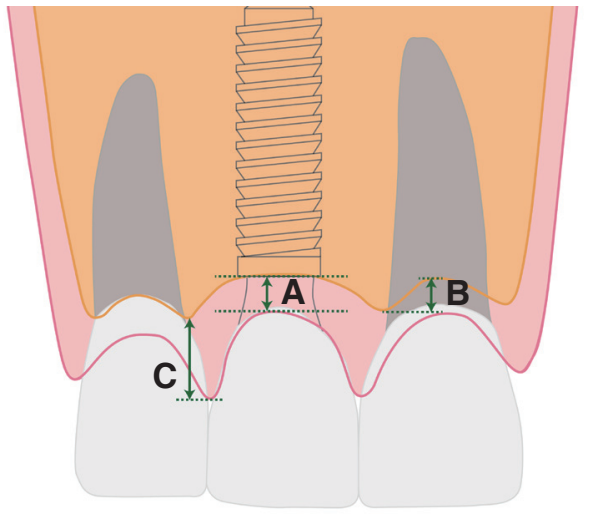

Fig. 4. Optimal implantation depth. (A) Marginal gingiva $\sim$ buccal bony crest $\approx 3-4 \mathrm{~mm}$. (B) Interproximal bony crest $\sim$ buccal bony crest $\approx 3-4 \mathrm{~mm}$. (C) Interproximal contact (interdental papilla) interproximal bony crest $\leq$ $5 \mathrm{~mm}$.

에는 약간 더 깊게 식립할 수 있으며, 이로 인해 지대주나 보철물의 출현각이 급격하지 않고, 출현윤곽이 자연스러 워질 수 있다.

임플란트의 수평적 위치는 변연치은 높이에 영향을 미 친다. ${ }^{5}$ 수평적으로 임플란트 플랫폼이 약간 구개측에 위 치하는 것이 협측치은퇴축(midbuccal recession)을 방지 할 수 있으며, 잔존 협측골은 $1.8 \mathrm{~mm}$ 이상의 두께를 가 져야 한다(Fig. $5 \mathrm{~A}){ }^{28}$ 또 다른 기준으로 교합면에서 밨을 때, 임플란트 플랫폼의 바깥 면(outer surface)이 주변치 아의 협측면을 연결한 가상선에서 $2 \mathrm{~mm}$ 이상 안쪽으로 들어오는 것이 좋다. ${ }^{28,29}$ 또한, 임플란트와 지대주 계면은 가장 취약한 부분으로 이 부위에서 협측치은퇴축이 일어
나 치은정점(gingival zenith)이 형성되는 경향이 있기 때 문에, 술자가 원하는 치은정점(zenith)의 위치에 임플란 트 플랫폼의 중앙이 위치되도록 하는 것이 좋으며, 치은 정점의 위치는 인접치아와 대칭으로 형성해주어야 심미 적이다(Fig. $5 \mathrm{~B}){ }^{27}$ 발치 후에 즉시 임플란트를 식립하는 것은 발치 후에 잔존하는 협측 골의 두께가 최소 $1 \mathrm{~mm}$ 이상 되는 경우에 추천이 되며, 즉시 임플란트 식립을 했 을 때에는 발치와의 협측골 안쪽면(inner surface)에서 임 플란트 플랫폼의 바깥면까지 $2 \mathrm{~mm}$ 이상 확보되어야 하 기 때문에 ${ }^{27,30,31}$ 최종적으로 식립 후의 임플란트 플랫폼의 협측 바깥면에서 협측골의 바깥면까지 총 $3 \mathrm{~mm}$ 이상이 되어야 한다(Fig. 5 C).

임플란트의 3차원적 위치에서 가장 중요한 것은 임플 란트의 협설 경사이다. 얇은 협측골에 임플란트가 협측 으로 경사되어 식립되면 지대주가 치조제의 정상(top) 부 위가 아닌, 협측 경사면을 뜷고 나오게 되고 이에 따라 인 접치보다 임플란트의 변연치은이 근단쪽에 위치하게 되 는 협측치은퇴축이 생기기 때문이다(Fig. 6A). 심하게 협 측으로 경사되어 식립된 임플란트의 경우, 지대주나 보철 물을 의도적으로 최대한 설측으로 수정하더라도 협측의 치은쪽으로 형성되는 지대주 나사 구멍(screw hole)의 위 치는 변경이 불가능하기 때문에 결국 치관의 길이는 길어 지게 된다(Fig. 6B). 그리고 협측으로 기울어진 임플란트 는 일반적으로 플랫폼 수준에서 협측골 두께를 얇게 만 들고, 이는 중, 장기적으로 협측골 흡수가 일어나 치료 완 료 후의 협측치은퇴축을 유발할 수 있다. 따라서, 상기의 기준을 충족하여 임플란트를 식립할 수 없는 잔존 치조 골이나 발치와를 가지고 있는 경우에는, 골이식을 통한
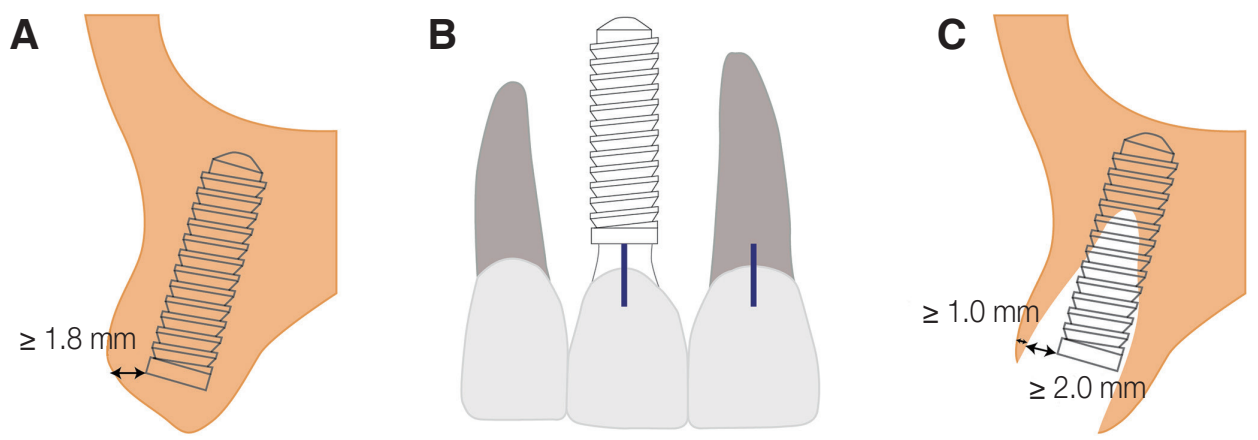

Fig. 5. Implant position and angle of implant inclination. (A) Delayed implantation- buccal bone thickness of $1.8 \mathrm{~mm}$ or more at the level of the implant shoulder. (B) Symmetry of gingival zenith of implant and natural teeth. (C) Immediate implantation after extraction-facial bone wall at least $1 \mathrm{~mm}$ in thickness and minimum distance of $2 \mathrm{~mm}$ between the implant platform and the inner surface of the facial socket wall. 

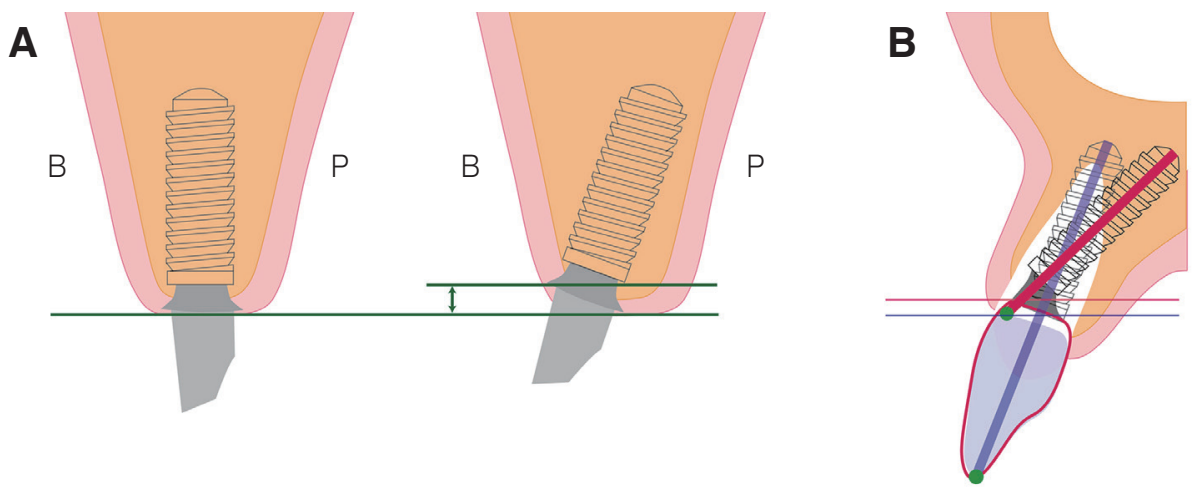

Fig. 6. Buccolingual inclination of implant. (A) Buccal implant inclination leads to long crown in relation to ideal implant position. (B) Too buccally angulated implant have apically positioned screw access hole: midfacial gingival recession.

치조골 증대술을 선행하거나, 발치 후에 즉시 임플란트 식립하지 않고 발치와 보존술(socket preservation)을 시 행하여 이상적인 치조골 형태를 먼저 형성한 후, 임플란 트를 협측 경사되지 않도록 지연 식립하는 것이 매우 중 요하다. ${ }^{32-34}$

임플란트 주위 연조직의 두께가 변연치은 높이에 미치 는 영향은 'creeping' 현상을 통해 이해할 수 있다. ${ }^{24}$ 이는 치은의 두께가 증가할수록 치은의 높이가 높아지는 것으 로 자연치아의 경우 치은 두께가 1 이면 높이가 1.5 로 나 타난다. ${ }^{35}$ 이에 반해 임플란트는 주위 연조직의 높이와 두께의 비율이 1:1.5로 나타나기 때문에, 임플란트가 자 연치아보다 변연 치은의 두께 증가에 따른 변연치은의 높이 증가가 2배 이상 어렵다는 것을 의미한다(Fig. 7). ${ }^{36}$

임플란트 주위 연조직의 두께를 확보하는 데에는 고 전적인 임플란트보다 플랫폼 스위칭이 디자인된 임플 란트가 플랫폼 직상방 부위에서 연조직 두께가 더 두껍 기 때문에 변연치은의 높이를 유지하는 데에 유리하다 (Fig. 8). ${ }^{18,37}$ 임플란트 주위 연조직 두께와 높이를 보존하 는 다른 효과적인 방법은 발치 후 즉시 임플란트 식립을 한 뒤 바로 임시보철물을 수복하여 주변 연조직이 붕괴 되지 않도록 하는 것이다. ${ }^{32,38}$ 그러나 발치 후 즉시 임플 란트 식립이 주변 골 흡수와 골유착 방해 및 심미적 문제 를 더 많이 유발시킨다는 문제점을 지적하는 연구결과도 많다. ${ }^{39,40}$ 따라서 발치 후 즉시 임플란트 식립이 적용되는 경우는 제한적이며, ${ }^{20}$ 본인은 다음의 전제조건을 만족하 는 증례에서 발치 후 즉시 임플란트 식립을 시행하는 것 을 추천한다.

(1) 발치와의 협측골 두께 $\geq 1 \mathrm{~mm}$

(2) 발치와의 협측골 높이 $\geq$ 정상적인 인접치의 협측골

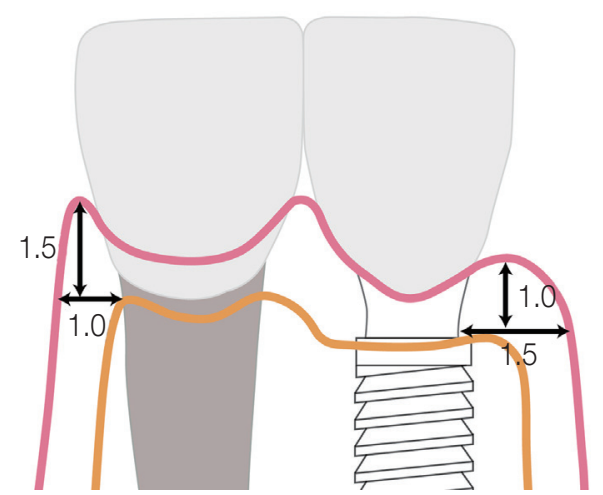

Fig. 7. Creeping effect. Gingival height/width: natural teeth-1.5/1.0, implant- 1.0/1.5.

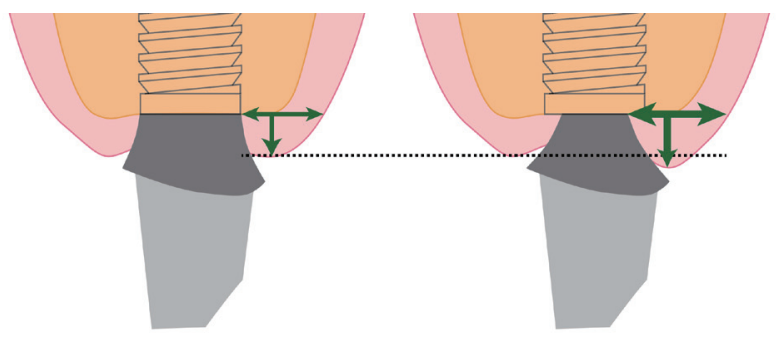

Fig. 8. Platform switching is advantageous in peri-implant soft tissue preservation by having thicker gingiva.

높이

(3) 발치와의 변연치은 높이 $\geq$ 정상적인 인접치의 변연 치은 높이

(4) 협측으로 경사되지 않은 치조골 : 치근단 부위에 심 한 함몰 부위(lateral fossa)가 없는 치조골 
따라서 실제 임상에서는 발치 후, 즉시 임플란트를 식 립하는 것보다는 골이식을 시행하거나 치조골보존술을 시행해야 하는 증례가 많으며, 즉시 임플란트를 식립하 는 경우라 할지라도 골이식을 동반해야만 하는 경우도 많다. ${ }^{20,24}$ 하지만, 골이식도 연조직의 두께에 미치는 악 영향이 존재한다. 이는 이완 절개나 차폐막의 사용, 피판 의 이동과 같은 일련의 과정으로 인하여 연조직으로 가 는 혈류가 차단, 감소되어 결과적으로 하방의 골조직과 는 무관하게 상방의 연조직이 위축되는 결과가 발생하는 것이다. ${ }^{24}$ 이러한 경우에는 다양한 연조직 이식을 고려할 수 있으며, 이는 연조직 두께를 최대 $1.5 \mathrm{~mm}$ 정도 증가시 켜 'creeping'을 통한 최대 $1 \mathrm{~mm}$ 정도의 변연치은의 높이 상승을 기대할 수 있다. ${ }^{5,8}$ 하지만, 연조직 이식은 임플란 트 주위 골이 건전하고 풍융한 경우에만 시행하는 것이 중요하며, 치조제 위축의 원인이 연조직이 아닌 하부 골 조직의 상실이나 결함에 있다면, 이는 연조직 이식이 아 닌 골조직을 보강하는 방향으로 치료계획을 세워야 한 다. 즉, 중요한 것은 보철치료 전단계인 일련의 수술과정 (발치, 골조직 및 연조직 증대술, 임플란트 식립 등)을 통 해 수직, 수평적으로 과도할 만큼의 풍융한 치조제를 미 리 만들어 놓는 것이 유리한데, 이는 이후에 임시보철물 을 이용하여 심미적인 치은을 형성(molding)하는 과정이 부족한 치조제를 가진 경우보다 풍융한 치조제에서 훨씬 빠르고 손쉽기 때문이다.

지대주 및 보철물의 볼록한(convex) 치은 연하의 협측 외형은 협측 연조직을 압박하여 즉각적으로 협측 및 치 근단 쪽으로 변위시키며 중장기적으로 연조직의 두께를 얇게 만든다. 반대로 오목한(concave) 지대주 및 보철물 의 형태는 연조직 공간을 확보해주는 효과를 통해 연조 직의 두께를 보장하고 'creeping'을 통하여 치관측으로
변연치은이 상승되도록 도와준다(Fig. 9). 따라서 지대주 의 점막 관통 부위(trans-mucosal part)는 오목한 형태가 연조직 두께를 확보하고, 'creeping'을 유발한다는 측면 에서 변연치은의 퇴축을 막는데 유리하며, 특히 지대주의 협측은 오목한 형태가 좋다. ${ }^{8}$ 또한 이러한 원리를 이용하 여, 경미한 변연치은 높이의 편차는 지대주와 임시보철물 의 외형 수정을 통해 조정이 가능하다. ${ }^{8}$ 임시보철물이나 지대주 점막관통부위에 레진을 첨가 또는 삭제하여 그 부위의 연조직을 압박하거나 반대로 연조직 공간을 확보 함으로써 변연치은을 의도적으로 퇴축시키거나 반대로 치관측으로의 성장을 유도할 수도 있다.

골이식 후, 하부 골조직의 양은 정상이나 상부 연조직 의 양과 질이 부족하여 치조제가 위축된 경우라면, 상기 와 같이 지대주 및 임시보철물의 점막관통부위를 오목 하게 형성해주는 것이 중요하며, 더불어 치관의 협측 치 경부 $1 / 3$ 부위를 완만하게 줄여 위축된 치조제와 자연스 럽게 연결되도록 하여 착시에 따른 자연스러움을 얻도록 하는 것이 매우 유용한 방법이다(Fig. 10). ${ }^{41}$ 그리고 이렇 게 잘 수정되고 적응된 임시보철물의 형태를 최종 지대주 및 보철물로 정확하게 이전시키는 것은 보철 치료 성공 에 필수적인 과정인데, 이를 위해서 custom impression coping을 만들어 이용하는 방법이 많이 알려져 있다. $22-43$ 최근에 들어서는 디지털 방식을 활용하여 맞춤형 지대주 를 만드는 방법이 사용되고 있으며, 이는 적절하게 형성 된 연조직의 형태를 임시수복물의 치은연하 부위의 스캔 을 통해 왜곡없이 반영할 수 있다. 디지털을 이용하는 방 식은 기존의 custom impression coping을 사용하는 것과 비교하여 체어시간과 재료도 절약할 수 있으며, 환자가 느끼는 불편감도 감소시킬 수 있습니다. 또한 기공과정 에서도 모형작업이나 별도의 모형 스캔작업이 없이 바로
A

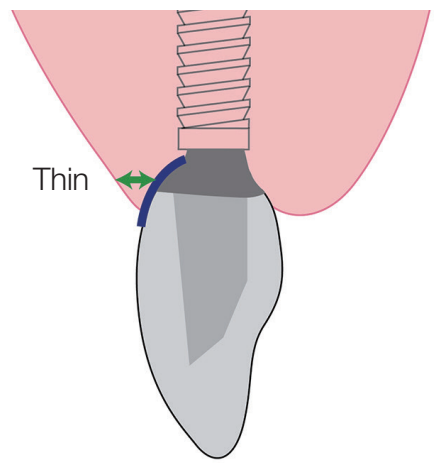

B

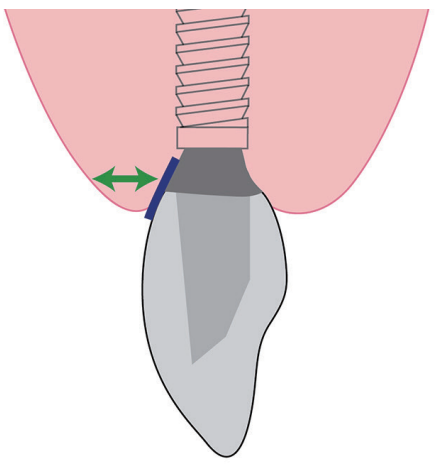

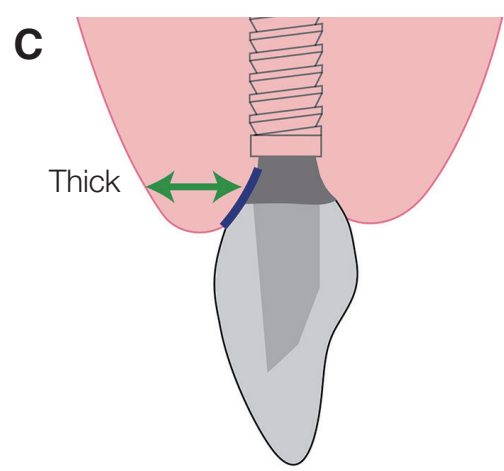

Fig. 9. The effect of abutment shape. (A) Convex shape- thinner gingiva. (B) Flat shape. (C) Concave shape- thicker gingiva. 

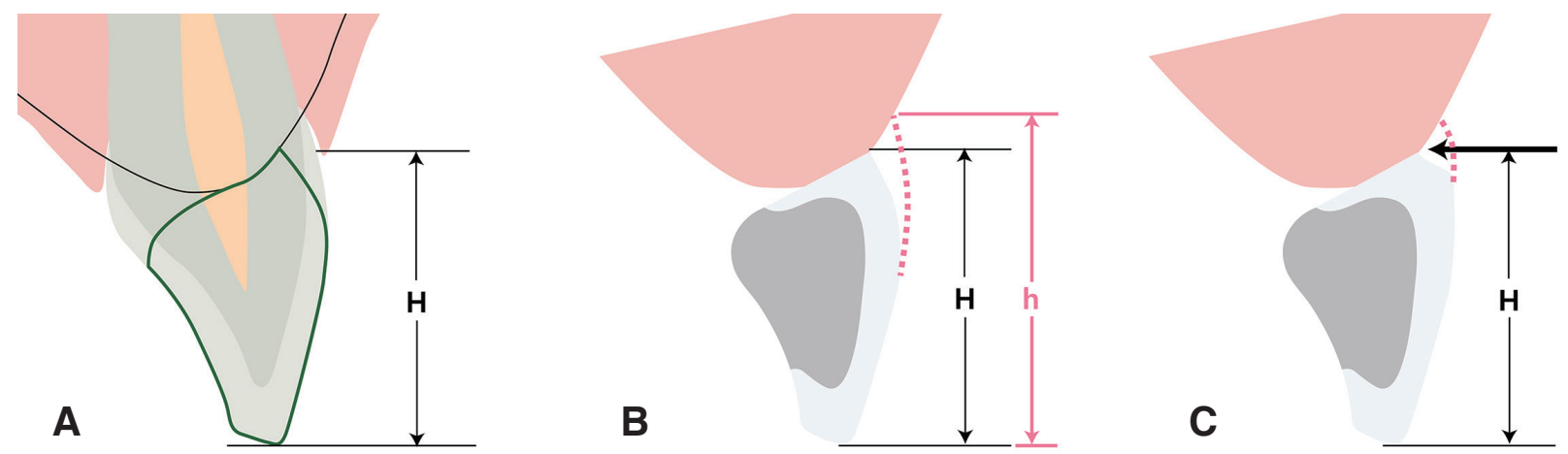

Fig. 10. Altering the facial contour of the implant crown. (A) An implant crown should have the same incisogingival heght $(\mathrm{H})$ as the original tooth. (B) Correctly contoured implant crown (h = longer crown height). (C) Incorrectly contoured implant crown (arrow: trapping food and creating esthetically unacceptable shadow).
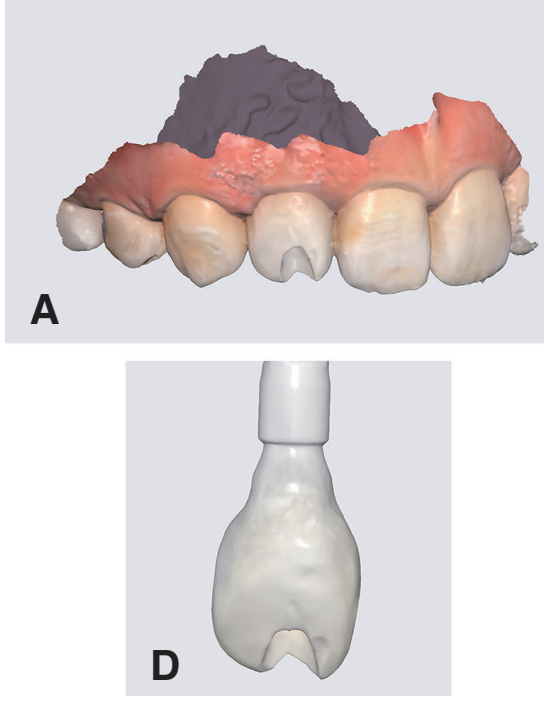

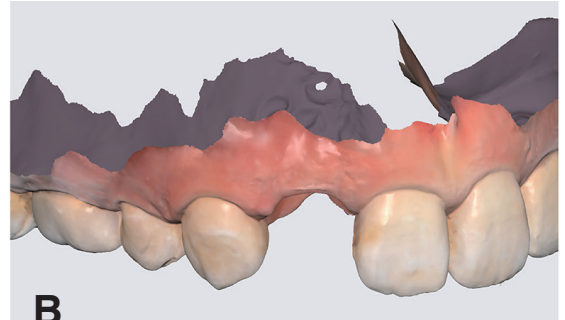

B

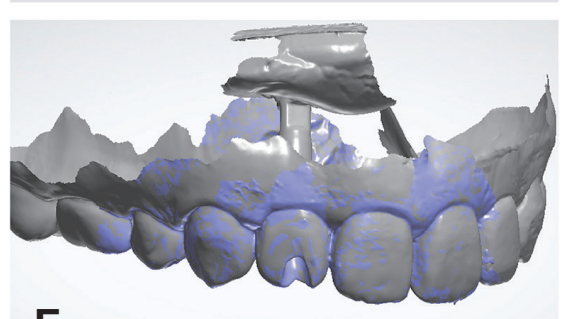

E
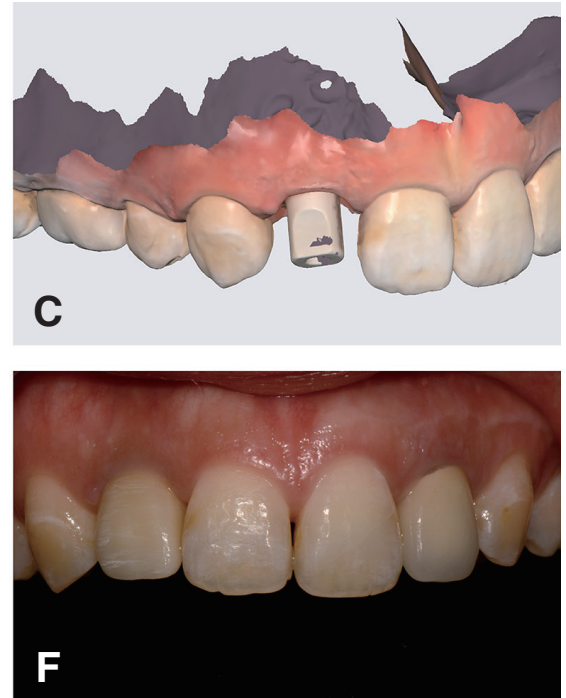

Fig. 11. A digital technique for replicating provisional restoration. (A) Surface architecture with provisional restoration in place. (B) Peri-implant mucosa. (C) Implant position. (D) Emergence profile of interim prosthesis. (E) A, B, C, and D superimposed to generate impression with implant position, peri-implant mucosa, and emergence profile. (F) Definitive restoration.

맞춤형 지대주 제작을 위한 소프트웨어를 이용할 수 있 어 시간과 비용이 절감할 수 있는 장점이 있다(Fig. 11). ${ }^{44}$

불필요한 변연치은의 퇴축을 막기 위해서는 수술이나 보철 과정 중의 외상을 최소화하는 것이 중요하다. 수술 시에 봉합사로 인한 변연치은 부위의 흔적이나 부분적 인 퇴축은 오래 지속되기 때문에 최대한 주의를 하는 것 이 좋다. 또한, 가능한 경우라면 피판을 거상하지 않는 최소 침습적인 수술을 하는 것을 추천한다. ${ }^{32}$ 수술로 인 한 외상을 줄일 수 있는 방법은 임플란트 가이드를 이용 하는 방법이 있다. Cone beam computed tomography
(CBCT), virtual treatment planning software, stereolithographic surgical templates를 이용한 임플란트 가이 드 수술은 해부학적으로나 보철적으로 모두 적절하게 임 플란트의 식립위치를 결정할 수 있는 좋은 방법이다. ${ }^{45}$ 이 를 통해 보다 예지성 있는 치료가 가능하고, 수술 시에 발생하는 오차도 줄일 수 있다. ${ }^{46}$ 상악 전치부와 같이 심 미적인 부위에 임플란트 가이드를 통한 무절개 임플란트 식립이 가지는 큰 장점은 피판거상으로 발생할 수 있는 치은 퇴축과 치간 유두 소실을 감소시킬 수 있다는 점이 다. ${ }^{47}$ 그러나 이러한 무절개 임플란트 가이드 수술을 하 
기 위해서는 협설측, 근원심으로 충분한 양의 잔존 치조 제가 있는 경우에 행해야 하며, 앞서 언급하였던 전치부 임플란트의 심미성을 달성하기 위한 조건들은 변함이 없 다.

또한, 인접한 치아나 임플란트에서 이미 변연치은의 퇴 축을 보이고 있거나 방사선학적 평가 시, 심한 협측 골소 실이 발견되었다면, 인접치아(임플란트)를 포함하지 않 는 판막 디자인을 하는 것이 술 후, 인접한 치아(임플란 트)의 추가적인 치은 퇴축을 막아 환자의 심미적인 불평 을 예방할 수 있다. 또한 2차 수술 시에는 연조직 펀치 술 식(soft tissue punch technique)을 사용하여 설측에서 접 근하는 최소 크기의 구멍을 만들고 치유지대주를 연결하 면 절개선 및 봉합사에 의한 불필요한 흔적을 남기지 않 을 뿐만 아니라, 자연스럽게 연조직이 협측으로 밀리면서 협측 연조직을 두껍게 확보할 수 있다.

임시보철물의 수정을 위한 지대주의 잦은 탈착은 점막 부착(mucosal seal)을 파괴하고 연조직 두께를 감소시켜 부정적인 영향을 끼친다는 연구결과가 많다. ${ }^{48,49}$ 따라서 지대주 탈착을 동반하는 임시보철물 수정은 최소한으로 시행하고 한 번 수정할 때에 최대한 정밀하게 조정하는 것이 좋다. 또한, 의도치 않은 스크류의 풀림과 지대주의 흔들림은 임플란트 주위조직에 자극이나 염증을 유발시 킬 수 있기 때문에 발생 즉시 재조임을 통한 고정을 해주 는 것이 중요하다.

임플란트 보철물 변연에서 치조골까지의 거리가 1.5 $\mathrm{mm}$ 보다 가까운 경우에는 임플란트 주위염 발생가능성 이 커진다. ${ }^{50}$ 그래서 지대주의 마무리선(finish line)과 보 철물 변연의 위치를 불필요하게 치은 연하로 깊게 설정하 지 않는 것이 중요하다. 따라서 임시보철물 수복단계에 서 임시보철물을 충분한 기간 동안 사용하여 더 이상의 연조직 변화가 발생하지 않은 것을 관찰하였다면, 보철 물의 변연 위치는 치은연하 $0.5-1.0 \mathrm{~mm}$ 보다 더 하방으 로 형성하지 않는 것이 임플란트 주위조직에 대한 자극 을 최소화하고 구강위생관리를 용이하게 하며 의도치 않 은 잉여시멘트의 잔류를 막을 수 있겠다.

\section{치간 유두(Interdental papilla)}

단일 임플란트의 치간 유두의 높이는 인접한 자연치의 치간골(interdental bone)에 의해 결정된다. ${ }^{51}$ 인접치아의 상태가 건전하다면, 해당치아를 발거한 후에도 협측 골 에 비해 치간골은 건전한 인접치아 때문에 쉽게 흡수되
지 않는다. 하지만, 어떤 이유로든 치간골은 한번 흡수되 어 사라지면 협측골과 달리 치료를 통하여 회복시키거나 재생하는 것이 매우 어렵다. 즉, 단일 임플란트의 치간 유 두는 인접치아의 치간골 높이에 절대적인 영향을 받으며, 한 번 소실된 치간골은 재생시키는 것이 어렵기 때문에, 치간골 소실을 동반한 임플란트 주위의 치간유두 상실은 회복시키기가 매우 힘들다.

단일 임플란트의 경우 Tarnow에 따르면, 보철물의 인 접면 접촉점에서 치간골까지의 거리가 $5 \mathrm{~mm}$ 이하라 면 모든 증례에서 치간 유두가 채워진다고 하였다(Fig. 4C). ${ }^{52}$ 따라서 임플란트 보철물의 인접면 접촉점을 치관치근방향으로 긴 'long proximal contact'으로 형성하는 것이 좋으며, ${ }^{8}$ 인접치아의 형태가 사각형의 모양을 가지 고 있거나, 인접치아를 함께 수복하는 경우라면 인접면 접촉점 설정을 용이하게 할 수 있어 치간 유두 형성에 더 유리하다.

다수의 임플란트를 식립하는 경우, 임플란트를 협측 치조골정 높이에 맞추어 식립하게 되면 임플란트와 임플 란트 사이에는 치간골이 없는 상태가 되고 평균 $3.5 \mathrm{~mm}$ 의 낮은 높이를 가지는 치간 유두가 만들어진다(Table 2, Fig. 12A). 이런 경우 보철물은 최대한의 'long proximal contact'을 만들어주어야 한다. ${ }^{53}$ 고려할 수 있는 또 다른 방법으로는 임플란트들을 정상 깊이보다 침하 식립하게 하여 플랫폼 상방의 얇은 협측 골은 흡수되더라도 상대 적으로 두꺼운 임플란트들 사이의 치간골이 유지된다면, 임플란트를 정상깊이대로 식립하는 것보다 변연치은 높 이에 비하여 치간유두가 상대적으로 높게 보일 수 있다 (Fig. 12B). 하지만 이렇게 침하식립을 하게 되면 플랫폼 상방으로 잔존한 얇은 협측골은 자연스럽게 흡수되면서 시간이 지남에 따라 변연치은 퇴축이 발생하고 치관 길

Table 2. Predictably achievable interproximal soft tissue dimensions measured from the most coronal interproximal height of bone (Salama, 1998) ${ }^{46}$

\begin{tabular}{clc}
\hline Class & Environment & $\begin{array}{c}\text { Height of } \\
\text { interproximal papilla }\end{array}$ \\
\hline 1 & Tooth-Tooth & $5.0 \mathrm{~mm}$ \\
2 & Tooth-Pontic & $6.5 \mathrm{~mm}$ \\
3 & Pontic-Pontic & $6.0 \mathrm{~mm}$ \\
4 & Tooth-Implant & $4.5 \mathrm{~mm}$ \\
5 & Implant-Pontic & $5.5 \mathrm{~mm}$ \\
6 & Implant-Implant & $3.5 \mathrm{~mm}$ \\
\hline
\end{tabular}


A

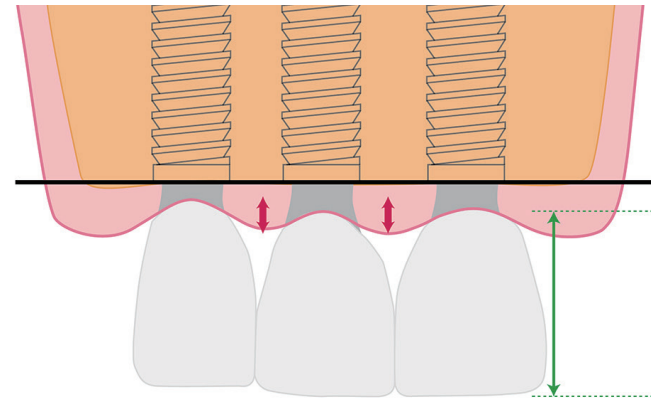

B

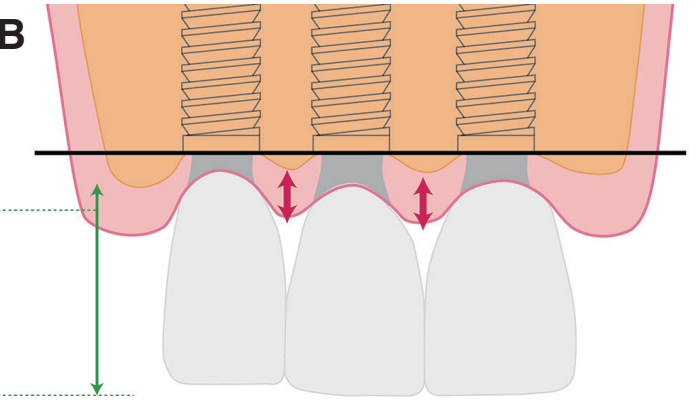

Fig. 12. Interdental papilla of multiple implants. (A) Crestal placement of implants-lower interdental papilla. (B) Subcrestal placement of implants-higher inderdental papilla, but longer crown.

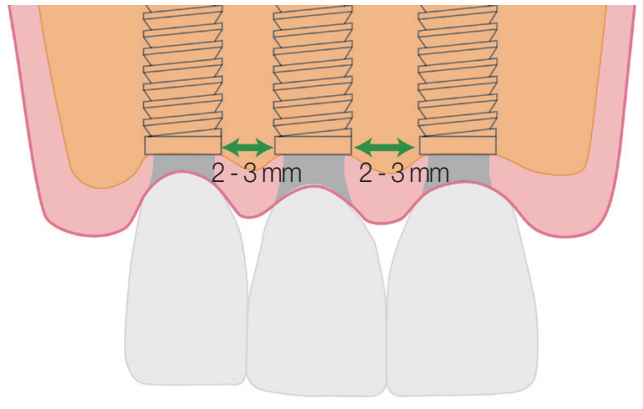

Fig. 13. Inter-implants distance.

이가 길어지게 되므로, 술자는 적절한 치관 길이를 선택 할지, 치간유두의 형성을 선택할지 결정하여 임플란트 식 립깊이를 조절해야 한다. 치간 유두의 높이는 임플란트 와 임플란트 사이의 경우 $3.5 \mathrm{~mm}$ 로 가장 낮게 형성되며, 임플란트와 가공치(pontic) 사이의 경우에는 $5.5 \mathrm{~mm}$ 로 더 높게 형성시킬 수 있다. 따라서 다수의 임플란트를 식 립할 때에는 상실된 치아의 개수대로 임플란트를 식립하 는 것보다는 역학적으로 중요하지 않은 부위를 가공치로 처리하는 것이 치간 유두 형성에 훨씬 유리하다. ${ }^{8}$

치간 유두 형성에는 치간골이 중요하며 이는 다른 부 위 치조골과 다르게 한 번 소실되면 재생시키기가 어려워 손상시키지 않도록 주의하는 것이 매우 중요하다. 임플 란트 간 식립 거리를 $2-3 \mathrm{~mm}$ 이상 확보하지 않으면 치 간골이 더 쉽게 흡수될 수 있어 치간유두 소실을 유발할 수 있다(Fig. 13). ${ }^{8}$ 외과적 술식 자체도 치간 유두 상실의 주된 원인이 된다. 발치 등을 포함한 시술에서 치간골에 가해지는 불필요한 외력을 줄이는 것이 중요하고, 치간 골로의 혈류 감소가 발생하지 않도록 세심하게 시술하는
것이 좋다. 그리고 치주낭 깊이가 $6 \mathrm{~mm}$ 이상이라면 치간 유두를 포함하지 않은 판막 디자인을 추천하는데, ${ }^{7}$ 이는 Tarnow가 언급했던 것처럼 치간골 상방으로 $4.5 \mathrm{~mm}$ 이 상의 치간 유두는 회복되지 않아서, $6 \mathrm{~mm}$ 이상의 치주낭 을 가진 경우에서는 술 후에 최소 $1.5 \mathrm{~mm}$ 이상의 치간유 두 소실이 발생하기 때문이다. ${ }^{51}$

\section{결론}

전치부 임플란트의 연조직 심미는 세심한 일련의 과정 들이 복합적이고 유기적으로 적용되어야 달성할 수 있는 부분이다. 외상과 자극을 최소화하는 수술, 골이식을 통 한 골조직 증강, 임플란트 식립 시 임플란트의 3차원적 위치, 필요한 경우 연조직 이식술의 시행, 임시보철물의 충분한 경과관찰과 적절한 수정이 성공적인 전치부 임플 란트의 연조직 심미를 얻기 위해 고려해야 할 치료과정 들이다. 환자마다 이 과정들이 모두 필요한 것은 아니지 만, 치료 전 뿐 아니라 치료 과정 중에서도 지속적인 치료 계획에 대한 고찰를 통해 적절한 시기에 필요한 술식을 적용하는 것이 환자의 심미적 만족도와 전치부 임플란트 보철물의 안정된 장기적 예후를 보장할 수 있다.

\section{ORCID}

Yeon-Hee Park https://orcid.org/0000-0002-9183-9244

Seung-Geun Ahn https://orcid.org/0000-0002-9105-931X

Kyoung-A Kim https://orcid.org/0000-0002-2923-5351

Jae-Min Seo https://orcid.org/0000-0001-5095-4046 


\section{References}

1. Fuentealba R, Jofré J. Esthetic failure in implant dentistry. Dent Clin North Am 2015;59:227-46.

2. Papaspyridakos P, Chen CJ, Singh M, Weber HP, Galluci GO. Success criteria in implant dentistry: a systematic review. J Dent Res 2012;91:242-8.

3. Higginbotoom FL. Implant as an option in the esthetic zone. J Oral Maxillofac Surg 2005;63:33-44.

4. Chang M, Odman PA, Wennstrom JL, Andersson B. Esthetic outcome of implant-supported singletooth replacements assessed by the patient and by prosthodontists. Int J Prosthodont 1999;12:335-41.

5. Dursun E, Lin GH, Taheri S, Chu SJ, Wang HL, Tozum TF. A comparison of esthetic features of pre-existing natural tooth versus post-implant restoration in the esthetic zone: aretrospective 12-month follow-up. Int J Oral Maxillofac Implants 2018;33:919-28.

6. Wittneben JG, Wismeijer D, Bragger U, Joda T, Abou-Ayash S. Patient-reported outcome measures focusing on aesthetics of implant- and tooth-supported fixed dental prostheses: a systematic review and meta-analysis. Clin Oral Impl Res 2018;29:22440.

7. Misch CE. Contemporary implant dentistry. 3rd ed. St. Louis; Mosby; 2008. p. 738, 889.

8. Thalji G, Bryington M, De Kok IJ, Cooper LF. Prosthodontic management of implant therapy. Dent Clin North Am 2014;58:207-25.

9. Fetner M, Fetner A, Koutouzis T, Clozza E, Tovar N, Sarendranath A, Coelho PG, Neiva K, Janal MN, Neiva R. The effects of subcrestal implant placement on crestal bone levels and bone-toabutment contact: a microcomputed tomographic and histologic study in dogs. Int J Oral Maxillofac Implants 2015;30:1068-75.

10. Cochran DL, Bosshardt DD, Grize L, Higginbottom FL, Jones AA, Jung RE, Wieland M, Dard M. Bone response to loaded implants with nonmatching implant-abutment diameters in the canine mandible. J Periodontol 2009;80:609-17.

11. Huang B, Meng H, Zhu W, Witek L, Tovar N, Coelho PG. Influence of placement depth on bone remodeling around tapered internal connection im- plants: a histologic study in dog. Clin Oral Implants Res 2015;26:942-9.

12. Jung RE, Jones AA, Higginbottom FL, Wilson TG, Schoolfield J, Buser D, Hammerle CHF, Cochran DL. The influence of non-matching implant and abutment diameters on radiographic crestal bone levels in dogs. J Periodontol 2008;79:260-70.

13. Aloise JP, Curcio R, Laporta MZ, Rossi L, da Silva AMA, Rapoport A. Microbial leakage through the implant-abutment interface of morse taper implants in vitro. Clin Oral Implants Res 2010;21:32835.

14. Koutouzis T, Fetner M, Fetner A, Lundgren T. Retrospective evaluation of crestal bone changes around implants with reduced abutment diameter placed non-submerged and at subcrestal positions: the effect of bone grafting at implant placement. J Periodontol 2011;82:234-42.

15. Tesmer M, Wallet S, Kououzis T, Lundgren T. Bacterial colonization of the dental implant fixtureabutment interface: an in vitro study. J Periodontol 2009;80:1991-7.

16. Lazzara RJ, Porter SS. Platform switching: a new concept in implant dentistry for controlling postrestorative crestal bone levels. Int J Periodontics Restorative Dent 2006;26:9-17.

17. Enkling N, Johren P, Klimberg V, Bayer S, Mericske-Stern R, Jepsen S. Effect of platform switching on peri-implant bone levels: a randomized clinical trial. Clin Oral Implants Res 2011;22:1185-92.

18. Farronato D, Santoro G, Canullo L, Botticelli D, Maiorana C, Lang NP. Establishment of the epithelial attachment and connective tissue adaptation to implants installed under the concept of "platform switching: a histologic study in minipigs. Clin Oral Implants Res 2012;23:90-4.

19. Elian N, Cho SC, Froum S, Smith RB, Tarnow DP. A simplified socket classification and repair technique. Pract Proced Aesthet Dent 2007;19:99-104.

20. Gluckman H, Pontes CC, Du Toit J. Radial plane tooth position and bone wall dimensions in the anterior maxilla: a CBCT classification for immediate implant placement. J Prosthet Dent 2018;120:50-6.

21. Kan JY, Rungcharassaeng K, Umezu K, Kois JC. Dimensions of the peri-implant mucosa: an evalua- 
tion of maxillary single implants in humans. J Periodontol 2003;74:557-62.

22. Katafuchi M, Weinstein BF, Leroux BG, Chen YW, Daubert DM. Restoration contour is a risk indicator for peri-implantitis: a cross-sectional radiographic analysis. J Clin Periodontol 2018;45:225-32.

23. Rojas-Vizcaya F. Biological aspects as a rule for single implant placement. The 3A-2B rule: a clinical report. J Prosthodont 2013;22:575-80.

24. Funato A, Ishikawa T. 4D implant therapy: esthetic considerations for soft-tissue management. 1 st ed. Tokyo; Quintessence; 2012. p. 87, 110.

25. Kois JC. The restorative-periodontal interface: biological parameters. Periodontol 2000 1996;11:29-38.

26. Becker W, Ochsenbein C, Tibbetts L, Becker BE. Alveolar bone anatomic profiles as measured from dry skulls. Clinical ramifications. J Clin Periodontol 1997;24:727-31.

27. Cook R, Lim K. Update on perio-prothodontics. Dent Clin North Am 2019;63:157-74.

28. Spray JR, Black CG, Morris HF, Ochi S. The influence of bone thickness on facial marginal bone response: stage 1 placement through stage 2 uncovering. Ann Periodontol 2000;5:119-28.

29. Grunder U, Gracis S, Capelli M. Influence of the 3-D bone-to-implant relationship on esthetics. Int J Periodontics Restorative Dent 2005;25:113-9.

30. Morton D, Chen ST, Martin WC, Levine RA, Buser D. Consensus statements and recommended clinical procedures regarding optimizing esthetic outcomes in implant dentistry. Int J Oral Maxillofac Implants 2014;29:216-20.

31. Kim YK. Bone graft in immediate implantation after anterior tooth extraction. J Korean Dent Assoc 2017;55:725-32.

32. Lekovic V, Kenney EB, Weinlaender M, Han T, Klokkevold P, Nedic M, Orsini M. A bone regenerative approach to alveolar ridge maintenance following tooth extraction. Report of 10 cases. J Periodontol 1997;68:563-70.

33. Vance GS, Greenwell H, Miller RL, Hill M, Johnston H, Scheetz JP. Comparison of an allograft in an experimental putty carrier and a bovine-derived xenograft used in ridge preservation: a clinical and histologic study in humans. Int J Oral Maxillofac
Implants 2004;19:491-7.

34. Barone A, Aldini NN, Fini M, Giardino R, Calvo Guirado JL, Covani U. Xenograft versus extraction alone for ridge preservation after tooth removal: a clinical and histomorphometric study. J Periodontol 2008;79:1370-7.

35. Wennstrom JL. Mucogingival considerations in orthodontic treatement. Semin Orthod 1996;2:4654.

36. Nozawa T, Enomoto H, Tsurumaki S, Ito K. Biologic height-width ratio of the buccal supra-implant mucosa. Eur J Esthet Dent 2006;1:208-14.

37. Canullo L, Iurlaro G, Iannello G. Double-blind randomized controlled trial study on post-extraction immediately restored implants using the switching platform concept: soft tissue response. Preliminary report. Clin Oral Implants Res 2009;20:414-20.

38. Bhola M, Neely AL, Kolhatkar S. Immediate implant placement: clinical decisions, advantages, and disadvantages. J Prosthodont 2008;17:576-81.

39. Araujo MG, Wennstrom JL, Lindhe J. Modeling of the buccal and lingual bone walls of fresh extraction sites following implant installation. Clin Oral Implants Res 2006;17:606-14.

40. Botticelli D, Persson LG, Lindhe J, Berglundh T. Bone tissue formation adjacent to implants placed in fresh extraction sockets: an experimental study in dogs. Clin Oral Implants Res 2006;17:351-8.

41. Rosenstiel SF, Land MF, Fujimoto J. Contemporary fixed prosthodontics. 5th ed. St. Lousi; Elsevier; 2016. p. 566-7.

42. Elian N, Tabourian G, Jalbout ZN, Classi A, Cho SC, Froum S, Tarnow DP. Accurate transfer of peri-implant soft tissue emergence profile from the provisional crown to the final prosthesis using an emergence profile cast. J Esthet Restor Dent 2007; 19:306-14.

43. Tsai BY. A method for obtaining peri-implant softtissue contours by using screw-retained provisional restorations as impression copings: a clinical report. J Oral Implantol 2011;37:605-9.

44. Liu X, Liu J, Mao H, Tan J. A digital technique for replicating peri-implant soft tissue contours and the emergence profile. J Prosthet Dent 2017;118:264-7.

45. Jung RE, Schneider D, Ganeles J, Wismeijer D, 
Zwahlen M, Hammerle CH, Tahmaseb A. Computer technology applications in surgical implant dentistry: a systematic review. Int J Oral Maxillofac Implants 2009;24:92-109.

46. Scotti R, Pellegrino G, Marchetti C, Corinaldesi G, Ciocca L. Diagnostic value of NobelGuide to minimize the need for reconstructive surgery of jaws before implant placement: a review. Quintessence Int 2010;41:809-14.

47. Koutrach M, Nimmo A. Preservation of existing soft-tissue contours in the transition from a tooth to an implant restoration in the esthetic zone using a flapless approach: a clinical report. J Prosthodont 2010;19:391-6.

48. Becker K, Mihatovic I, Golubovic V, Schwarz F. Impact of abutment material and dis-/re-connection on soft and hard tissue changes at implants with platform-switching. J Clin Periodontol 2012; 39:774-80.

49. Alves CC, Munoz F, Cantalapiedra A, Ramos I, Neves M, Blanco J. Marginal bone and soft tissue behavior following platform switching abutment connection/disconnection- a dog model study. Clin Oral Implants Res 2015;26:983-91.

50. Derks J, Schaller D, Hakansson J, Wennstrom JL, Tomasi C, Berglundh T. Effectiveness of implant therapy analyzed in a Swedish population: prevalence of peri-implantitis. J Dent Res 2016;95:43-9.

51. Kan JY, Rungcharassaeng K. Interimplant papilla preservation in the esthetic zone: a report of six consecutive cases. Int J Periodontics Restorative Dent 2003;23:249-59.

52. Tarnow DP, Magner AW, Fletcher P. The effect of the distance from the contact point to the crest of bone on the presence or absence of the interproximal dental papilla. J Periodontol 1992;63:995-6.

53. Salama H, Salama MA, Garber D, Adar P. The interproximal height of bone: a guidepost to esthetic strategies and soft tissue contours in anterior tooth replacement. Pract Periodontics Aesthet Dent 1998;10:1131-41. 


\section{전치부 임플란트의 연조직 심미성을 달성하기 위한 외과적, 보철적 고려사항}

박연희 ${ }^{1}$ 전임의, 안승근 ${ }^{1}$ 교수, 김경아 ${ }^{2}$ 부교수, 서재민 ${ }^{1 *}$ 교수

${ }^{1}$ 전북대학교 치의학전문대학원 치과보철학교실 및 구강생체과학연구소

${ }^{2}$ 건양대학교 의과대학 치과학교실

임플란트 치료에 대한 기능적 성공률이 높아짐에 따라 심미성에 대한 새로운 성공 기준이 제시되고 있다. 이에 따라 치과 의사 및 환자가 가지는 심미적 기준도 높아졌으며, 임플란트 심미 수복 결과에 대한 만족도 또한 높아지고 있다. 임플란 트 식립하기 전 치료계획 수립 과정, 임플란트 수술 과정, 수술 후 보철수복 과정이 모두 심미적 결과에 영향을 미칠 수 있 으며, 임플란트의 심미적 실패를 예방하기 위해서는 치조골, 연조직, 그리고 임플란트의 세 가지 요소를 고려하여 각 단 계마다 적절한 처치를 통해 이루어질 수 있다. 성공적인 전치부 임플란트의 연조직 심미를 얻기 위해서는 외상과 자극을 최소화하는 수술, 골이식을 통한 골조직 증강, 임플란트 식립 시 임플란트의 3차원적 위치, 필요한 경우 연조직 이식술의 시행, 임시보철물의 충분한 경과관찰과 적절한 수정을 고려해야 한다.

(구강회복응용과학지 2021;37(4): 186-98)

주요어: 치과 임플란트; 치과 심미성; 임플란트 고정성 보철물; 변연치은; 치간유두

*교신저자: 서재민

(54896) 전북 전주시 덕진구 백제대로 567 , 전북대학교 치의학전문대학원 치과보철학교실

Tel: 063-250-2696 | Fax: 063-250-2218 | E-mail: jmseo@jbnu.ac. kr

접수일: 2021년 8월 19일 | 수정일: 2021년 11월 18일 | 채택일: 2021년 11월 23일 